Article

\title{
Sustainable Community Sanitation for a Rural Hospital in Haiti
}

Jay N. Meegoda *, Hsin-Neng Hsieh, Paul Rodriguez and Jason Jawidzik

Department of Civil and Environmental Engineering, New Jersey Institute of Technology, University Heights, Newark, NJ 07102, USA

* Author to whom correspondence should be addressed; E-Mail: meegoda@njit.edu; Tel.: +1-973-596-2464; Fax: +1-973-596-5790.

Received: 23 October 2012; in revised form: 6 December 2012 / Accepted: 12 December 2012 / Published: 18 December 2012

\begin{abstract}
A fully sustainable sanitation system was developed for a rural hospital in Haiti. The system operates by converting human waste into biogas and fertilizer without using external energy. It is a hybrid anaerobic/aerobic system that maximizes methane production while producing quality compost. The system first separates liquid and solid human waste at the source to control carbon to nitrogen ratio and moisture content to facilitate enhanced biodegradation. It will then degrade human waste through anaerobic digestion and capture the methane gas for on-site use as a heating fuel. For anaerobic decomposition and methane harvesting a bioreactor with two-stage batch process was designed. Finally, partially degraded human waste is extracted from the bioreactor with two-stage batch process and applied to land farming type aerobic composter to produce fertilizer. The proposed system is optimized in design by considering local conditions such as waste composition, waste generation, reaction temperature, residence time, construction materials, and current practice. It is above ground with low maintenance requirements.
\end{abstract}

Keywords: bio-digester; human waste; sustainable; developing countries; compact; two-chamber; low water content; above ground

\section{Introduction}

Supplying clean drinking water in developing countries is one of the greatest challenges facing humanity. In many developing nations, sources of drinking water are contaminated because of the lack of sanitation facilities. Currently, wastewater treatment in developed nations is provided by septic 
systems or centralized wastewater treatment plants with sanitary sewer systems. Such systems are not sustainable since septic systems need large leaching fields and centralized wastewater treatment plants requiring energy to operate and use water to transport waste. On the other hand, human waste is an energy source with high nutrient content, which can be recovered by proper design of an anaerobic bioreactor. One of the by-products in anaerobic decomposition is methane. Methane is a greenhouse gas that is 25 times more damaging than carbon dioxide but has a high heating value. Hence, methane should be captured and used as a combustion fuel, which will benefit our planet with a decreased greenhouse gas in the atmosphere. Any community sanitation system that is developed should be built on-site and self-contained so it will not need a leaching field with the possibility of groundwater contamination. Such a design can promote sustainable development in the developed as well as developing world and realize the potential for positive social, economic, and environmental impacts.

The idea of sustainable design occurred due to a request from a hospital in Haiti for a new design. In 2009, the Engineers without Borders chapter of the New Jersey Institute of Technology (NJIT-EWB) was contacted by the Hôpital Sacré Coeur in Milot, Haiti, due to a problem the hospital encountered. The Hôpital Sacré Coeur uses a septic system for outdoor lavatories. Waste from the lavatories is discharged into a septic pit. The septic pit is not lined, so pathogens can easily leach into the groundwater. During floods, which are common in Haiti's precipitous climate, the pit has a tendency to overflow. During the 2009 rainy season, a team of visiting doctors became ill. Upon subsequent investigation, the Hôpital Sacré Coeur found that contamination of the hospital was due to overflow of the septic pit during floods, which caused the illnesses of visiting doctors. This also resulted in soil and water contamination in the surrounding area. The hospital requested NJIT-EWB to provide a practical solution to their waste disposal problem.

Therefore, the main objective of the project is to design a fully sustainable sanitation system that requires no external energy, processes all waste into useful products (biogas and fertilizer) and uses locally available materials for construction. NJIT-EWB team conducted a comprehensive literature search to obtain information and identify technologies for on-site and in situ wastewater treatment. A survey of the local conditions with respect to the wastewater generation and persons to be served was performed with the assistance of hospital workers. The hospital site was explored to investigate the possible layout of the treatment system. A search was also conducted for potential useful local materials and resources. Once the information collection was completed, the team initiated the design and cost estimate.

\section{Background Research}

In general, there are several ways to estimate the quantity of wastewater generated. Wastewater can be estimated by the waste production rate (gal/capita/day or liter/person/day) or by the fixture units (numbers of sinks, toilets, etc.). In developed nations such information can be easily obtained. For example, in the U.S., an average wastewater flow rate were reported to be $80-120 \mathrm{gal} / \mathrm{capita} /$ day (300-450 liter/capita/day) and in areas without sewers, the value is about $55 \mathrm{gal} / \mathrm{cap} / \mathrm{day}$ (210 liter/cap/day) [1]. The numbers are usually adjusted for variables such as income, season, existence of a water meters, etc. In the U.S., each person produces $0.22-0.3 \mathrm{lb} /$ day $(100-140 \mathrm{~g} /$ day $)$ feces and 0.2-0.35 gal/day (0.8-1.3 liter/day) urine [1]. The composition of raw waste for onsite 
system design is also well-known in developed nations. For example, the $\mathrm{BOD}_{5}$ (5-day Biochemical Oxygen Demand), TKN (Total Kieldahl Nitrogen), and total phosphorus are in the range of 215-540 mg/L, 30-80 mg/L, and 10-27 mg/L, respectively [1]. The carbon, nitrogen, and phosphorus content are high enough to allow wastewater to be decomposed without the need for additional nutrients [1].

\subsection{Onsite Treatment Technologies for Developed Nations}

Quite a number of technologies have been developed for onsite and in situ wastewater treatment. Two common primary treatment devices are septic tank and Imhoff tank. Both work as a combined settling and skimming tank and as an unheated-unmixed anaerobic digester. Since the detention time for liquid waste is rather short and treatment is often incomplete, the septic tank is often connected to a leaching field for further treatment through local soil. Sophisticated secondary treatment technologies include aerobic/anaerobic unit, aerobic unit, intermittent sand filter, recirculating granular medium filter, and constructed wetlands [2,3].

In recent years, newer designs have been developed. Some of these include composting toilet, household ATUs (Aerobic Treatment Units), chemical toilets, and incineration toilets. A composting toilet is designed to store and compost by bacterial digestion of human urine and feces, and small amounts of kitchen wastes. These are often used in places where a water supply is not available, such as in a mountain cabin, and to replace chemical toilets. Household-scale ATUs are commonly purchased, delivered, and installed as self-contained modules. It usually contains primary treatment (in some cases, only a screen), secondary treatment (generally, a suspended growth), a polishing tank (to remove additional contaminants, such as small particles or nutrients, as required to meet water-quality standards), and disinfection. A chemical toilet is a toilet using chemicals to deodorize the waste instead of simply storing it in a hole, or piping it away to a sewage treatment plant. These toilets are most commonly found on airplanes, trains, caravans, motor homes, and construction sites, identified with a blue-colored dye in the bowl water. Incineration toilets deposit wastes directly into the combustion chamber for incineration and reduce wastes to ash and evaporate the liquid. Incineration is fueled by gas, fuel oil, or electricity.

A movement is gaining momentum to obtain a solution to major environmental and public health problems in the developing world. The solution is not to invest in western-style flush toilets and centralized sewage systems but rather to develop toilets and decentralized waste-treatment technologies that use far less water. The latest development in this field occurred with the decision by the Bill and Melinda Gates Foundation to invest $\$ 40$ million in improving global sanitation. The California Institute of Technology developed a toilet that uses solar power to transform human waste into fertilizer and hydrogen. The hydrogen from the electrochemical reaction can be used in hydrogen fuel cells as energy, and the treated water can be reused to irrigate fields [4].

\subsection{Onsite Treatment Technologies for Developing Nations}

Many innovative forms of on-site sustainable sanitation systems have been developed for underdeveloped communities. These systems include: EcoSan toilets, Biogas generators, ArborLoo, SanPlat Latrine, Ventilated Improved Pit Latrine, and Pour-flush Toilet [5]. According to Mara et al. [5] these technologies are all considered a form of "ecological sanitation" where all 
nutrients in waste are recycled. Of particular interest is the biogas digester since these systems not only allow for the re-use of treated waste in agriculture but also extracted methane to be used as a biogas. Biogas technologies have been around for over a century since the introduction of anaerobic treatment. Germany, China and India have made the most development and progress with biogas technology implementation and research. Low rate bio-digesters in developing countries are most frequently used for animal waste.

One of the most common digesters in developing countries is the Chinese fixed dome bio-digester. The fixed dome digester is a continuous flow reactor that inputs animal waste from a mixing basin, which then displaces effluent (10\% total solids and 90\% water) from the reactor towards an outlet pipe. The biogas rises to the top of the dome where it is stored and collected. Marchaim [6] reported that 5 million family-sized fix dome digesters were operating in China by 1992 and 400,000-500,000 more are being built annually. The influence of bio-digesters in China towards sustainable sanitation development is evident. China has the advantage of having these systems available for decades along with trained local personal and national level standards to support the expansion of this sustained development.

Another form of digester is a batch digester, which works by filling a reactor with organic waste, sealing the reactor, and allowing the waste to decompose anaerobically for a certain retention time. During this retention time, waste cannot be added to the digester and must be filled into a separate digester. Batch digesters are a less popular system since it is not a continuous process unless paired with other batch digesters. Maya Farms in the Philippines used 30 batch digesters, filling and emptying one digester a day to ensure constant biogas supply [7]. It is not typically necessary to use this many batch digesters but the Maya Farms systems used small digester tanks that could only hold daily loads. An advantage of the batch reactor is that it does not require additional water to transport waste. Batch digesters have been tested to work as a dry fermentation process with up to $32 \%$ total solids before methane production decreases [8].

Bio-digesters have been mainly used for animal waste since animal feces contains a more optimal carbon to nitrogen ratio then human feces, however, there have been several cases where human waste digesters have been successfully implemented. A fixed dome biogas plant was installed in 2008 to treat blackwater and graywater at a public toilet station in Naivasha, Kenya. Approximately 300 people per day either used the pour-flush toilets, urinals or showers. The biogas is used at an onsite café to cook food and tea. The treated effluent from the digester is drained into an existing public sewer. Essentially the biogas plant serves as a pre-treatment for an inefficient wastewater treatment system at the end of the sewer [9].

Another example of a human waste bio-digester is the floating drum biogas plant implemented in 2006 at the Navsarjan Trust Vocational Training Institute DSK Campus in Gujarat, India. Approximately 300 students use the low-flush toilets (2L per flush) and urinals. The biogas is used for cooking and after approximate 30-day retention time effluent is sent to a drying bed to compost for agriculture purposes. The biogas plant experienced some problems with treating the blackwater due to the usage of 4-5 L of water being used for cleansing and flushing. With the increase in flush water, the biogas plant cannot properly treat the biogas plant and biogas production is also reduced [10]. 
From the above discussion it can be concluded that there are good systems to process human waste, but cannot be consider as sustainable systems as they are not optimized to recover all resources in human waste.

\section{The Design}

Before the engineering design, a process for waste treatment has to be selected first. Human waste is organic and can be biologically decomposed which can be achieved through aerobic and anaerobic process. An aerobic process is currently the major municipal sewage treatment process because it is more efficient and the degradation is faster. However, aerobic bacteria require the input of oxygen and the amount of oxygen that can be dissolved in water is rather low. In order to maintain the aerobic condition during waste degradation, equipment such as air compressors or mechanical aerators is provided, which means higher capital and maintenance costs. This requires energy, which may be a problem for underdeveloped areas. It is mentioned earlier that the septic tank is a well-established anaerobic treatment method. However, in this project, it is not feasible to use such system since after site investigation, it was found that flooding occurs when rainfall exceeds 4 inches, which is not uncommon and the surrounding soil has poor absorption characteristics. Most importantly, there is no leaching field for the existing septic tank and the effluent from the septic tank simply flows to an open canal as "gray water". So the design cannot be to simply modify or improve the existing system. A new self-sustainable anaerobic system will be required and the disposal of the both liquid and solid residuals has to be considered. However, an anaerobic system requires a longer time for decomposition requiring larger bioreactor. Hence, a coupled anaerobic and aerobic system was proposed. In this design, smaller bioreactors were proposed where waste was kept over shorter periods until maximum amount of methane is collected, then the partially decomposed waste is extracted and applied to land farming type aerobic composter to produce fertilizer. The coupled anaerobic and aerobic system is the novelty of the proposed system, which mimicked the sustainable Bio-Cell Project for municipal solid waste [11].

\section{Data Collection and Analysis}

Before the NJIT-EWB team visited the Hôpital Sacré Coeur, a questionnaire was prepared for the information to be collected. These included the cause of the problem, the best location to build the waste facility, information on local soil type, type of the currently used toilet, locally available construction material for the eco-toilet, availability of local labor, groundwater level, suitable locations to discharge treated wastewater or availability of a leaching field for septic tank, local water quality standard or regulations on wastewater discharge limit, number of daily users of the current latrine and design constraints. The required information was gathered from the hospital administrators and the mayor's office. This information was used in following sections.

In order to design a bioreactor to treat the waste and to ensure sustained biodegradation, the quantity of the wastewater generated and nutrient content of the waste must be known. Since the diet in Haiti is quite different from that of the U.S., information on major consumption food groups is needed. It was found that households in Haiti derive major share of food energy from cereals and vegetables. These two food groups provide more than one-half of all food supply and comprise nearly $70 \%$ of protein sources. Meat and dairy products, including fish and eggs, contributes less than $20 \%$ of 
protein [12]. The nitrogen and phosphorus content of the human waste from Haiti is estimated to be $2.1 \mathrm{~kg} / \mathrm{cap} /$ year and $0.3 \mathrm{~kg} / \mathrm{cap} / \mathrm{yr}$ [13], which are roughly half of the values found in the U.S. waste.

In 2009, the Hôpital Sacré Coeur housed 49,161 outpatient visits per year, 41 children per day at the Nutrition Center, and 73 beds to care for patients. From this information, it was determined that there is enough waste and energy content to efficiently power a biogas reactor at the hospital. To confirm this information, the NJIT-EWB research team visited Milot, Haiti in October 2010 and investigated the daily use of the public latrine of the Hôpital Sacré Coeur. A toilet attendant counted the number of people that used the toilet every hour on a weekday for the entire day. Approximate duration of usage by each occupant was also noted. This data was used to calculate the amount of daily waste. As shown in Table 1, the amount of fecal waste per day is approximated to be $25.9 \mathrm{~L}$ or 6.9 gallons. During the data gathering, treating the solid (feces) and liquid (urine) together or separately was also evaluated. Considerations were based on the amount of methane produced, how it may affect the system operation and maintenance, the capacity for holding the waste, duration of waste treatment, and the possibility of producing fertilizer and quality of output fertilizer, and the cultural acceptance.

Table 1. Daily Hospital Outpatient Latrine Usage Data.

\begin{tabular}{cc}
\hline Usage & Number \\
\hline Number of male visits per day & 220 \\
Number of female visits per day & 250 \\
Total Volume of Fecal Matter & $25.9 \mathrm{~L} /$ day \\
Total Volume of Urine & $122.8 \mathrm{~L} /$ day \\
\hline
\end{tabular}

\section{System Development}

Several factors would influence the operation of a bio-digester system, including Carbon to Nitrogen $(\mathrm{C} / \mathrm{N})$ ratio, $\mathrm{pH}$ and moisture content.

\subsection{Carbon to Nitrogen Ratio (C/N)}

A proper $\mathrm{C} / \mathrm{N}$ ratio is critical in optimizing the production of biogas. Both carbon and nitrogen play vital roles in biodegradation. Carbon is the energy source for microorganisms. Nitrogen is required for the synthesis of proteins and nucleic acids thus building cell structures. Fry [14] suggested that an optimum rate of digestion is a balanced C/N Ratio of between 20:1 and 30:1. Higher carbon content is not beneficial because it results in insufficient nitrogen to produce additional cells since the composition of cells has a fixed ratio of carbon to nitrogen. This in turn causes the system to limit the ability to process carbon into biogas and hence the excess carbon is wasted. On the other hand, higher nitrogen content causes production ammonia gas, which decreases the fertility of effluent sludge and hence the production of biogas. A lower $\mathrm{C} / \mathrm{N}$ ratio increases the loss of nitrogen by leaching (e.g., nitrate mobilization) and ammonia volatilization. The typical $\mathrm{C} / \mathrm{N}$ ratio of human feces ranges from 6:1-10:1 [14]. Combining the nitrogen rich urine to the solid waste would result in further reducing the $\mathrm{C} / \mathrm{N}$ ratio since roughly $80 \%$ of human nitrogen excretion is in urine [15]. Additionally, urine input adds too much variability in controlling the process. If a large amount of urine enters the 
system, the nitrogen level will become too high to keep a balanced $\mathrm{C} / \mathrm{N}$ ratio causing the gas production to be halted.

\subsection{Optimal $\mathrm{pH}$}

The optimal $\mathrm{pH}$ for bacteria to produce methane is in the range of 6.6 to 7.6 [16]. Operating the system at optimal $\mathrm{pH}$ reduces the amount of nitrogen being converted into ammonia gas since the conversion of ammonium to ammonia occurs around $\mathrm{pH} 9-10$. The high concentration of nitrogen in urine may adversely raise the $\mathrm{pH}$ of the mixture.

\subsection{Moisture Content}

When designing a bio-digester, it is important to maintain a consistent slurry mixture. Water is essential in a digester because bacteria take up the available substrates in a dissolved form. With increasing water content biogas production is enhanced, reaching its optimum at $91 \%-98 \%$ water by weight [17]. However, high water contents require larger reactor volumes and produces excess effluent that increases the volume and time for further decomposition. A literature search has also revealed that anaerobic digestion can take place under different moisture contents. A dry fermentation process is classified between $55 \%-75 \%$ water content and wet fermentation is classified as $>85 \%$ water content. A comparison of both processes is shown in Table 2.

Table 2. Comparison of Wet and Dry Fermentation [18].

\begin{tabular}{ccc}
\hline Process Mode & Dry & Wet \\
\hline Total Moisture Content & Low 55\%-75\% & High $85 \%-98 \%$ \\
Total solids content & High $25 \%-45 \%$ & Low $2 \%-15 \%$ \\
Reactor volume & Minimized & Increased \\
Conveyance technique & Expensive & Simple \\
Agitation & Difficult & Easy \\
Scamming & Little risk & High risk \\
Short circuit flow & Little risk & High risk \\
Solid-liquid separation & Simple & Expensive \\
Variety of waste components & Small & Great \\
\hline
\end{tabular}

Based on the above analysis, it was decided to use urine-diversion toilets to separate the urine and feces before treatment so as to optimize the methane production. Urine diversion requires a specially designed seat-riser or squatting slab or pan that is functionally reliable and socially acceptable. The basic idea of how to avoid mixing urine and feces is simple: the toilet user should sit or squat over some kind of dividing wall so that feces drop behind the wall and urine passes in front of the wall [19,20].

A continuous flow digester requires $\sim 90 \%$ water content so as to ease flow through the digester [21]. The anaerobic portion of the coupled anaerobic and aerobic system is a batch reactor (discontinuous operation), in which the reactor is filled with waste and discharged after a fixed retention time. Therefore, a dry fermentation with 55\%-75\% moisture content would be beneficial. In such a reactor volume is minimized, reducing costs and land-use. The digested output has lower water content, which simplifies transportation and facilitates composting. Water is conserved in the 
process, making this a more environmentally friendly alternative. Human feces has approximately $75 \%$ water content, which is the same moisture content required for dry fermentation process. The amount of urine produced is unpredictable on a day-to-day basis, so urine adds variable moisture, which makes it difficult to control the consistency of the input slurry. To achieve low water content for dry fermentation, the design avoids adding urine or additional water to the bioreactor. It is also important to avoid adding any drying material, such as ash, grass, leaves or paper, which would reduce water content through the increase of dry solid content. Hence, the proposed design would be a flush less urine-diversion toilet.

The proposed latrine will direct liquid and solid human waste into two separate collection compartments. The liquid waste will be diluted and used as a fertilizer. The solid waste will be directed to an anaerobic digester. Inside the anaerobic digester, waste will be converted to methane gas for on-site use as a heating fuel with the residual after desired retention time is extracted and converted into fertilizer by composting.

\section{Biogas Production}

Depending on the characteristics of input waste and the condition of the bioreactor (i.e., retention time, daily flow rate, $\mathrm{C} / \mathrm{N}$ ratio, temperature, and $\mathrm{pH}$ levels), the biogas production will vary. The biogas production has been calculated using two methods:

\section{(1) Using Online Data}

According to Updated Guide Book on Biogas Development [22], the gas production of human feces is between 0.02 to $0.028 \mathrm{~m}^{3}$ of biogas $/ \mathrm{kg}$. Assuming least optimal conditions, the lower value $0.02 \mathrm{~m}^{3}$ of biogas $/ \mathrm{kg}$ was used. Then using a flow rate number $25.9 \mathrm{~L} /$ day from Table 1 and assuming the approximate density of feces as that of water $(1 \mathrm{~kg} / \mathrm{L})$, the weight per day of human feces $=(25.9 \mathrm{~L} /$ day of human feces $) \times(1 \mathrm{~kg} / \mathrm{L})=25.9 \mathrm{~kg} / \mathrm{day}$. Therefore Biogas Production $=\left(0.02 \mathrm{~m}^{3}\right.$ biogas $\left./ \mathrm{kg}\right) \times(25.9 \mathrm{~kg} /$ day $)=0.518 \mathrm{~m}^{3} /$ day

\section{(2) Using Volatile Solids Method}

The flow rate Total Solid Feces (TS) in Table 1 is $25.9 \mathrm{~kg} /$ day. If Dry Solids (DS) $=25 \%$ of TS and Volatile Solids $(\mathrm{VS})=86.8 \%$ of DS [23], then VS $=(25.9 \mathrm{~kg} /$ day $) \times(0.25) \times(0.868)=$ $5.6203 \mathrm{~kg} /$ day. Furthermore, assuming a $45 \%$ reduction rate, Volatile Solids Destroyed $($ VS Destroyed $)=(5.6203 \mathrm{~kg} /$ day $) \times(0.45)=2.529 \mathrm{~kg} /$ day. Assuming that all destroyed volatile solids are converted into biogas, $2.529 \mathrm{~kg}$ of biogas is produced per day. Using the Density of Biogas (with $60 \% \mathrm{CH}_{4}$ ) $=0.0760 \mathrm{lb} / \mathrm{ft}^{3}=1.2174 \mathrm{~kg} / \mathrm{m}^{3}$ [24], Biogas Production = $(2.529 \mathrm{~kg} /$ day $) \times\left(1 \mathrm{~m}^{3} / 1.2174 \mathrm{~kg}\right)=2.077 \mathrm{~m}^{3} /$ day

Hence, the biogas production for the proposed toilet is expected to be between 0.5 and $2.0 \mathrm{~m}^{3} /$ day if the daily input of human feces is $25 \mathrm{~L}$ /day. Because it is difficult to approximate the operating conditions of this bioreactor with minimal data, the calculated values are approximations. The actual daily values will vary and may be lower or higher than the calculated values. However, these calculations provide a means of approximating the amount of useable energy provided by this bioreactor. 
The biogas generated will be used to heat water to produce hot water for the Hôpital Sacré Coeur. The amount of daily water heated from $25^{\circ} \mathrm{C}\left(77^{\circ} \mathrm{F}\right)$ to $50^{\circ} \mathrm{C}\left(120^{\circ} \mathrm{F}\right)$ can be determined using the Lower Heating Value of $60 \%$ methane biogas, which is approximately $570 \mathrm{BTU} / \mathrm{ft}^{3}$ [24]. Hence, the proposed bio-digester has the potential of heating approximately 25-100 gallons of water per day. By using the biogas to heat the water, there is less demand on the electric and gas water heaters, which are often rare or expensive resource in developing nations.

\section{Residence Time}

It is expected that the reactor operates at $35^{\circ} \mathrm{C}$ slightly above the average temperature of Haiti. If proper agitation is achieved in the reactor, $90 \%$ volatile solids reduction will be achieved in $30 \%$ less time [16]. Mixing is vital for any chemical reactions. It homogenizes the microbial species as well as the available substrate in the bioreactor. It prevents localized difference in temperature and chemical composition. Proper agitation breaks up the waste, eases the saturation of the feces into water and distributes organisms throughout the slurry, which allows for more biogas to be produced and rise through the waste. Reducing the time of volatile solids reduction also means shorter time for biogas production and shorter time for digestion. Faster digestion and shorter retention time result in a reduced volume of the digester. Figure 1 shows the benefit of mixing towards reducing the solids reduction rate, which is also temperature dependent. It is proposed to use Savonius wind mill for mixing making the design fully sustainable.

Figure 1. Effect of temperature and mixing on solids-reduction rate [16].

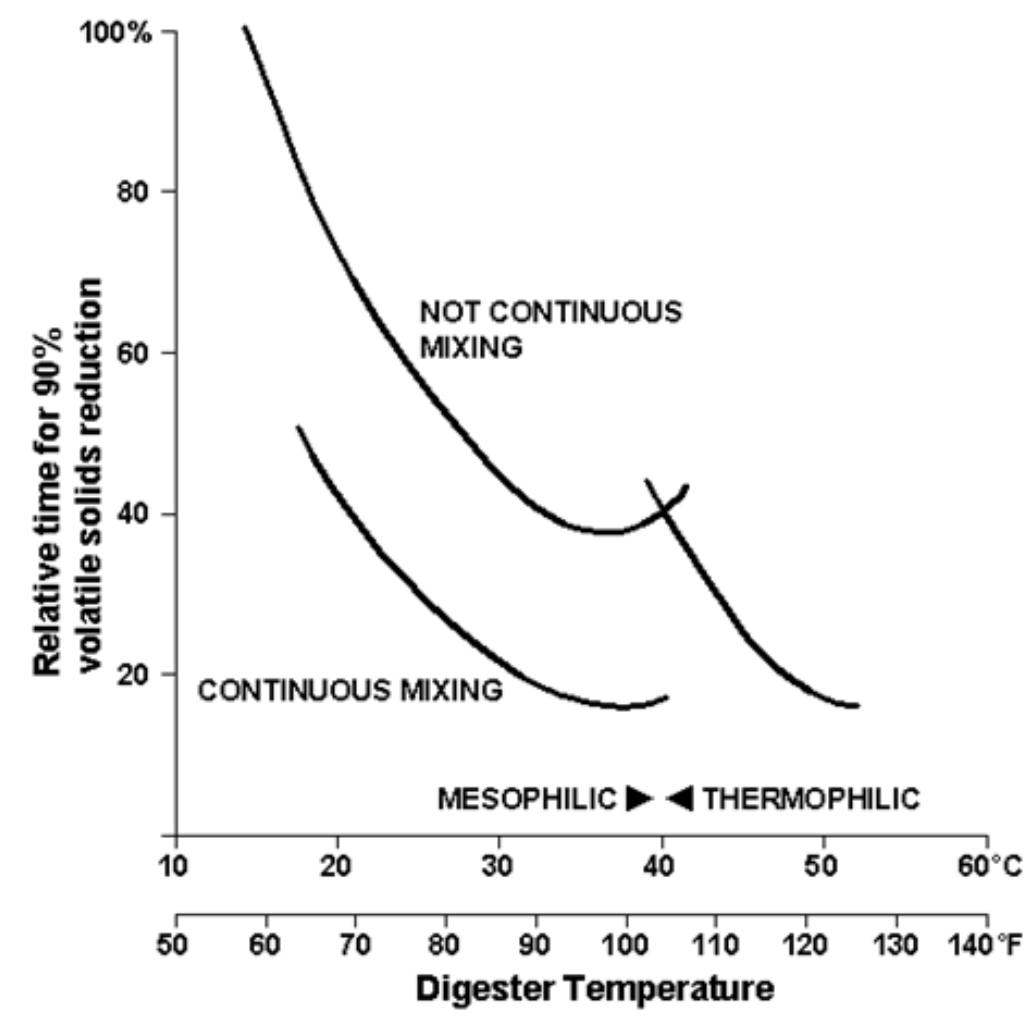

The bioreactor operation temperature at $35{ }^{\circ} \mathrm{C}$ is slightly higher than the average temperature in Milot, Haiti, is due to heat generated from biological activity. At $35^{\circ} \mathrm{C}$ Metcalf and Eddy [1] suggest a 
residence time of 10 days, while from batch reactors Liu et al., [25] suggested a residence time of 15 days. Since imperfect mixing is expected in this field scale bioreactor, a conservative residence time is assumed as one month. Hence it is expected that majority of methane generated can be extracted within one month. The schematic of a coupled anaerobic and aerobic system with the time line is shown in Figure 2. In this coupled anaerobic and aerobic system feces collected during the first month is treated under anaerobic conditions with mixing at $35{ }^{\circ} \mathrm{C}$ in the bioreactor during the second month. Then approximately $90 \%$ of volume is removed after two months. Removed waste is stored in twelve outdoor cells for one full year to decompose feces and other pathogens. Then the final product is used as fertilizer. The bioreactor is expected to yield an estimated 1525 pounds $(696 \mathrm{~kg})$ of compost per year. Trial calculations suggest that this compost volume is sufficient to treat one acre property, which would be supplemented by the diluted urine as liquid fertilizer.

Figure 2. Timeline of Bio-digester System Cycle from a Waste Perspective.

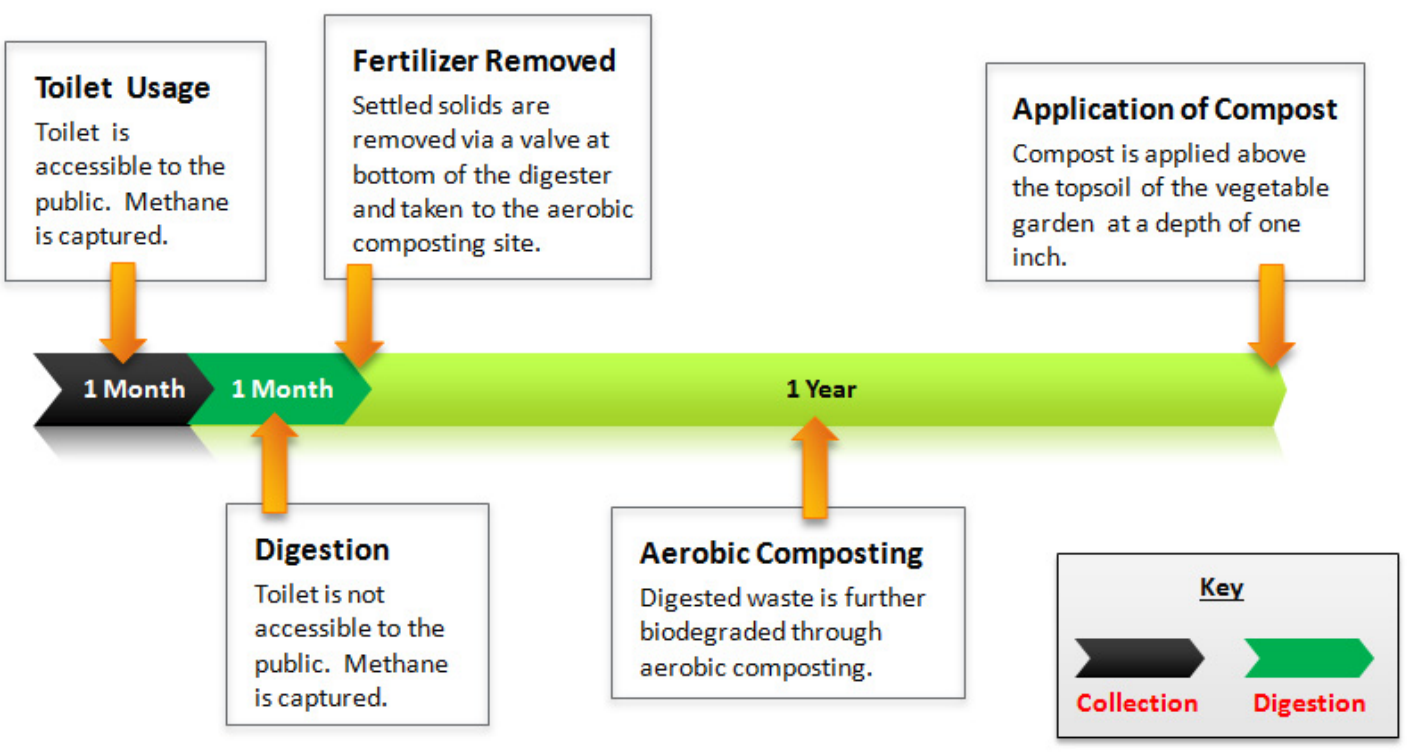

\section{The Sustainable Toilet}

A conventional batch process bio-digester is unattractive due to its many limitations. However, the proposed design is an improved batch process bio-digester. This digester is a continuous two-stage batch reactor that operates continuously without any pumps. Figure 3 shows the timeline of bio-digester system cycle from the toilet operation perspective. Two sets of toilets are constructed and during the first month users are allowed to use the first set where feces is collected in a chamber below the toilet, while the other toilet is closed and the collected feces is digested under anaerobic condition. At the end of the first month first toilet will be closed and collected feces are allowed to digest under anaerobic condition. At the same time, digested feces from the chamber under the second toilet are removed and toilet is opened for use. This is repeated every month.

The proposed design is an above ground, two-chamber, stirred-tank reactor. Only one of the two tanks collects waste at any given time, with cycles of one month of continuous public waste collection followed by a month of continuous public inaccessibility, in opposite synchronization with the each 
other. During the month of public waste collection, the waste is mixed daily and during the month public inaccessibility, the waste is allowed to decompose. After having been inaccessible for one month and prior to being put back into commission, the decomposed waste, which is settled at the bottom of the tank, is removed via a valve on the underside of the digester. This inert waste is to be composted via aerobic degradation and dehydration. After dehydration, the waste will be applied to the soil of the hospital's vegetable garden.

Figure 3. Timeline of Bio-digester System Cycle from a Toilet Perspective.

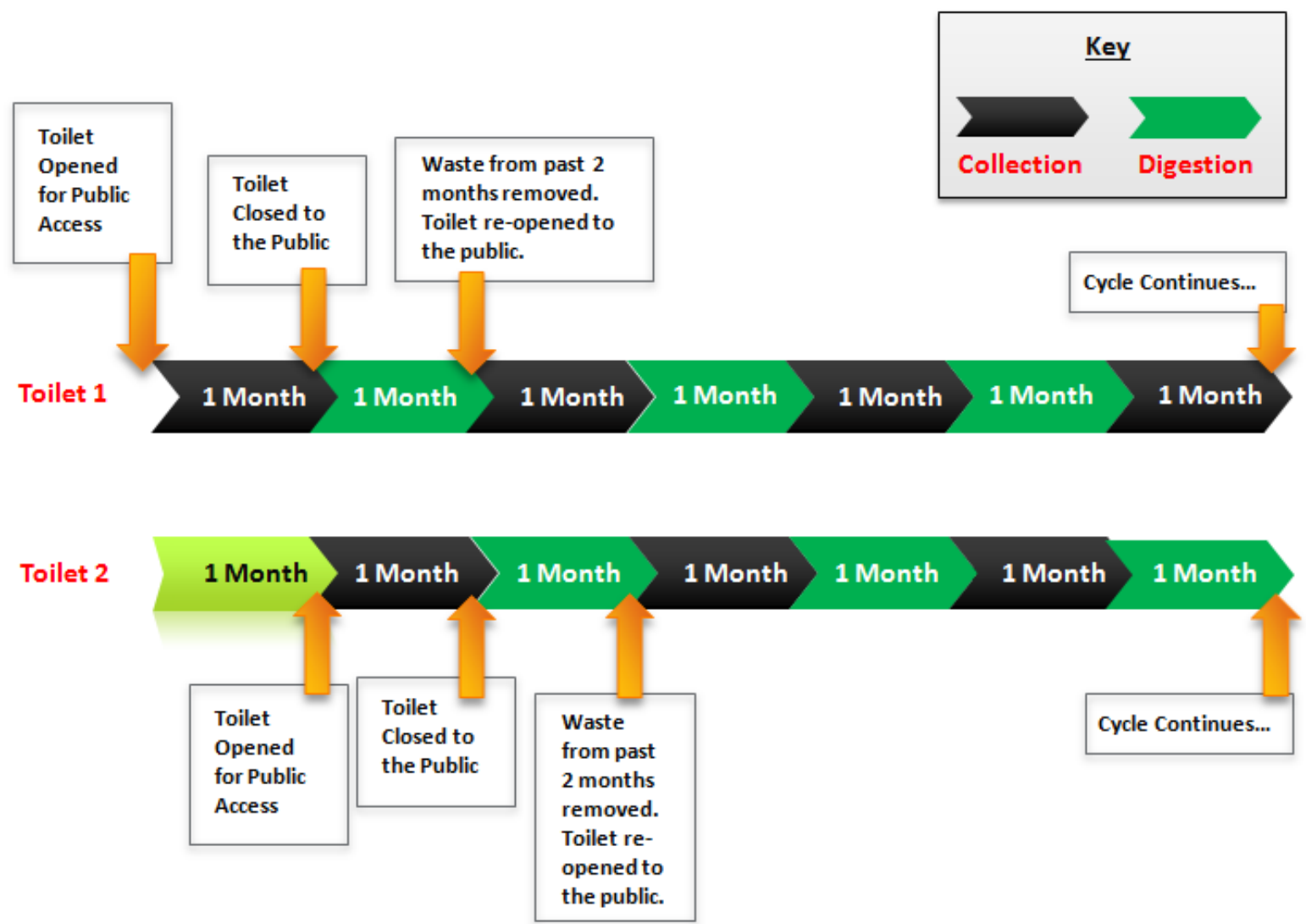

The proposed toilet is a no flush urine diversion system that will include an odor prevention valve. The design ensures adequate ventilation for the occupants and represents a completely sustainable system, when compared with the existing pit-based septic tank, which causes groundwater contamination and creates health and environmental hazards during floods. The design requires less costly upkeep than the existing pit-latrines, and the cost of maintaining the necessary environment for anaerobic digestion should be defrayed by reduced expenditure on fuel and crop gains from fertilization.

Due to the reduction in moisture content, liquid sludge treatment or sludge ponds are not necessary. This is particularly beneficial in underdeveloped communities where water is scarce and there is minimal space for sludge ponds or liquid sludge treatment would be too costly. The mostly solid sludge is simply mixed with dry compost in an aerobic composting site and allowed to decompose into a useful soil conditioner. The liquid slurry ( $\sim 10 \%$ total volume of tank) is left in the reactor as an inoculant for the next batch. It also serves to keep the inlet pipe covered inside the tank so that no air enters the tank. 
Figure 4 shows schematics of the proposed design. The proposed sustainable toilet consists of two units in the system which is not shown in Figure 4. Construction blue prints were generated and presented during the National Sustainable Design Expo 2011 (US EPA P3) held in Washington, D.C. in April 2011. Based on human feces volume of $25.9 \mathrm{~kg} /$ day a compact chamber of size $4 \mathrm{ft} \times 4 \mathrm{ft} \times 4 \mathrm{ft}$ including $1 \mathrm{ft}$ headspace was required. It was proposed to build this chamber with cement blocks filled with soil. Inside faces of the chamber was proposed to cover with $1 / 2$ " cement mortar and smoothed with cement paste. This would provide adequate insulation and prevent leakage. With such chamber design, it is possible to retain the heat generated during biodegradation to improve reaction kinetics.

Figure 4. Schematics of the Proposed Design.

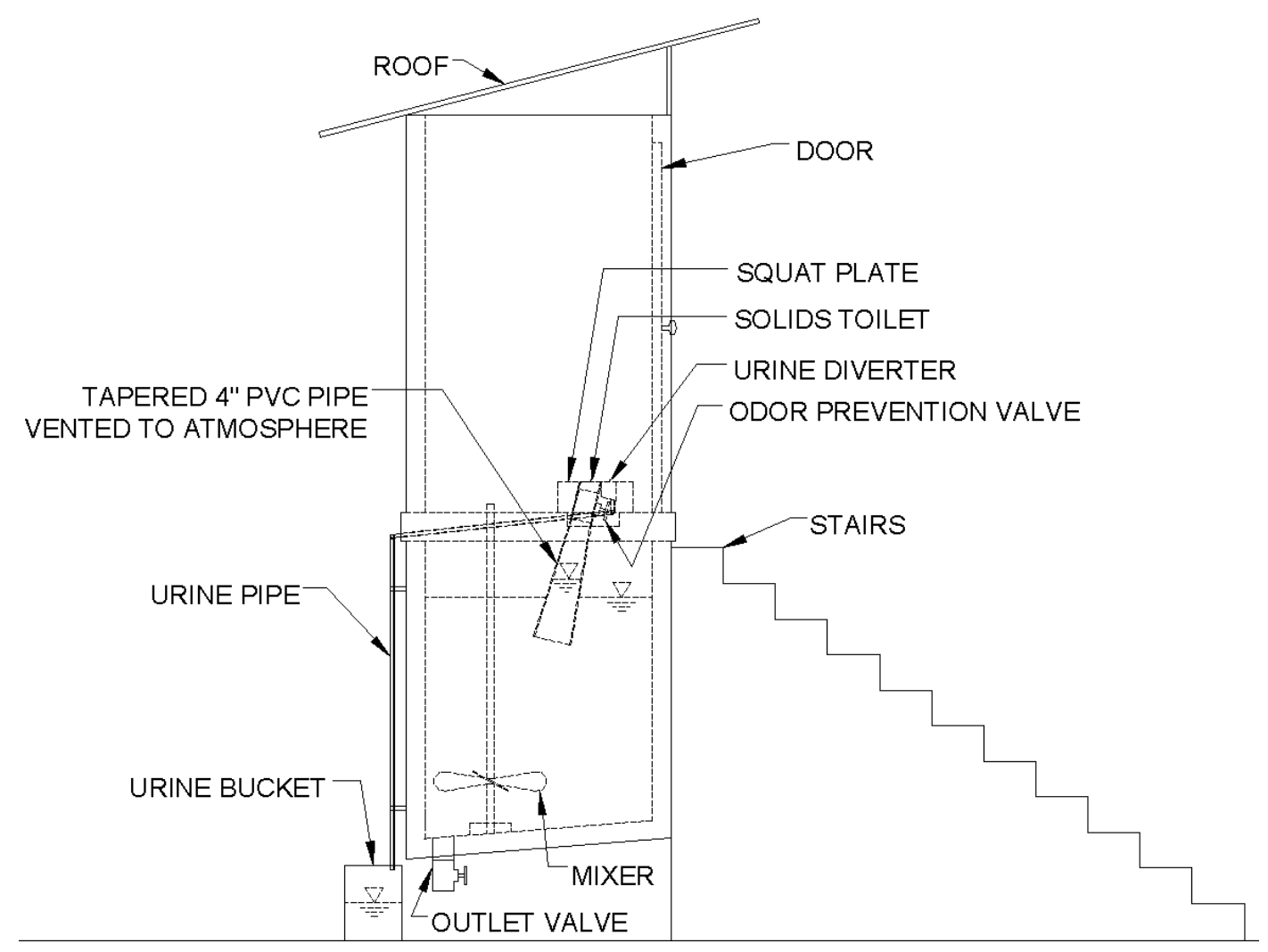

The Hôpital Sacré Coeur in Milot, Haiti is currently collecting funds to construct the proposed eco-toilet and the two chambers digester as well as twelve composting cells of size $8 \mathrm{f} \mathrm{t} \times 8 \mathrm{ft} \times 1 / 2 \mathrm{ft}$. NJIT-EWB has already developed the details of the waste collection pipe from the toilet to the chamber, which will prevent black splash, a digester stirring system which is connected to a Savonius wind mill and the special mechanical valve to prevent odor. The total construction cost of both material and labor for the two toilets with two chambers and 12 composting cells will be less than $\$ 25,000$. The above system can be operated at a cost of less than $\$ 1,000$ per year. The above cost values are based on the prevailing labor rate of $\$ 5$ per day in Milot, Haiti. This includes one dedicated person who would remove the partially digested waste from the reactor, remove urine collected from the separate chamber, dilute the urine in 1:5 ratio, switch the toilet, transfer to the composting facility, empty the one year old compost, apply the decomposed waste and diluted urine as fertilizer, and add the collected partially digested waste from the reactor to the empty cell of the composter each month. In addition this person would upkeep the toilet and the bioreactor including proper functioning of the 
windmill. Assuming the above design would last 25 years, the total cost would be approximately $\$ 6$ per day and less than $\$ 0.02$ per user per day.

NJIT-EWB is currently developing a proposal to introduce this sustainable sanitation system to other regions of the world with different climatic conditions (with different diets, average moisture levels and different temperatures). Once the new designs have been evaluated for reliability, the design will be given to humanitarian organizations seeking effective sanitation solutions.

The need for sanitation is obvious, with over 2 billion people without access to any sanitation system, and over 2 million annual deaths caused by sanitation-related diseases and poor hygienic conditions [26]. One critical area of interest is China. There is a sanitation crisis in China as with the economic expansion the central government is proposing to modernize the living conditions of 500 million strong rural populations with improved sanitation. If they adopt western style sanitation systems that would consume 20 times more water and 10 times more energy compared to current practice, it will make our planet unsustainable for all.

\section{Summary and Conclusions}

This paper presents sustainable design to handle human waste in Haiti, a developing nation. It was in response to an environmental problem encountered by a hospital in Haiti due to water contamination from an outflowing septic tank. The NJIT-EWB team investigated the problem, collected information, conducted a field study, analyzed data and designed innovated eco-toilets with a waste anaerobic treatment system for the hospital. The proposed design is a hybrid anaerobic/aerobic system that maximizes methane production while producing quality compost. A toilet is designed to separate liquid and solid human waste at the source to control carbon to nitrogen ratio and moisture content to facilitate enhanced biodegradation. The separated solid human waste is collected and decomposed in an anaerobic digester to capture the methane gas for heating or cooking. Residual from anaerobic digester is further decomposed in an aerobic digester and will be used as fertilizer. The use of the methane reducing greenhouse gas emissions will help maintain the current climate and sea level in their balanced state. Fertilizer will increase the fertility of the land, making it more arable and reversing desertification. Hence the widespread use of this eco-toilet will benefit the people of developing nations.

\section{Acknowledgments}

The financial support from the U.S. Environmental Protection Agency (EPA Agreement Number: SU834771) is gratefully acknowledged. Authors would like to acknowledge efforts of NJIT-EWB students Ernest Lee, Suryakant Sanghani, Daniel Martins, Lamount Landrum, Luigi Biele, Jilyan Decker, Christopher Ojeda, Steven Iacoviello, Julia Gayner, Kate Boardman, and Daniel Sosa.

\section{Conflict of Interest}

The authors declare no conflict of interest. 


\section{References}

1. Metcalf and Eddy Inc. Wastewater Engineering: Treatment, Disposal, Reuse, 3rd ed.; Technbanoglous, G., Burton, F.L., Eds.; McGraw-Hill: Columbus, OH, USA, 1991.

2. USEPA. Onsite Wastewater Treatment Systems Manual; EPA/625/R-00/008; Office of Water, Office of Research and Development: Washington, DC, USA, 2002. Available online: http://www.epa.gov/nrmrl/pubs/625r00008/html/625R00008.htm (accessed on 10 August 2011).

3. Zipper, C.; Reneau, R.B., Jr.; Jantrania, A. On-Site Sewage Treatment Alternatives; Virginia Coorperative Extension, Virginia Tech: Petersburg, VA, USA, 2009. Available online: http://www.pubs.ext.vt.edu/448/448-407/448-407.html (accessed on 15 August 2011).

4. Colopy, C. How No-Flush Toilets Can Help Make a Healthier World; Yale Environment 360: New Haven, CT, USA, 2012. Available online: http://e360.yale.edu/feature/how_noflush_toilets_can_help_make_a_healthier_world/2581/(accessed on 9 September 2011).

5. Mara, D.; Drangert, J.; Anh, N.; Tonderski, A.; Gulyas, H.; Tonderski, K. Selection of sustainable sanitation arrangements. Water Pol. 2007, 9, 305-318.

6. Marchaim, U. Biogas Process for Sustainable Development; Agricultural Services Bulletin 95; Food and Agriculture Organization of the United Nations, FAO: Rome, Italy, 1992. Available online: http://www.fao.org/docrep/T0541E/T0541E00.htm\#Contents (accessed on 12 September 2011).

7. Maramba, F.D. Biogas and Waste Recycling. The Philippines Experience, Maya Farms Division; Liberty Flour Mills Inc.: Manila, Philippines, 1978

8. Jewell, W.J.; Cummings, R.J.; Dell'Orto, S.; Fanfoni, K.J.; Fast, S.J.; Gottung, E.H.; Jackson, D.A.; Kabrick, R.M. Dry Fermentation of Agricultural Residues; Final Project Report for SERI, SERI/STR-231-1892; Cornell University: Ithaca, NY, USA, 1982.

9. Rieck, C.; Onyango P. Case Study of Sustainable Sanitation: Public Toilet with Biogas Plant and Water Kiosk Naivasha, Kenya; Sustainable Sanitation Alliance: Naivasha, Kenya, 2010. Available online: http://www.susana.org/docs_ccbk/susana_download/2-131-en-susana-cs-kenya-naivashabiogas-public-toilet-final-2009.pdf (accessed on 14 December 2012).

10. Wafler, M.; Heeb, J. Pour Flush Toilets with Biogas Plant at DSK Training Institute, Gujarat, India-Draft; Sustainable Sanitation Alliance: Gujarat, India, 2009 Available online: http://www.susana.org/docs_ccbk/susana_download/2-39-en-susana-cs-india-gurajat-navsarjandsk-2009.pdf (accessed on 10 September 2011).

11. Hettiaratchi, P.A. Bio-Cell Project, 2006. Available online: www.eng.ucalgary.ca/resrch civil/bio-cell-project/Hettiaratchi-bio-cell-project.htm (accessed on 14 December 2012).

12. Jensen, H.H.; Johnson, S.R.; Stampley, G. Nutrition in Haiti: Evidence from the Haiti Household Expenditure and Consumption Survey, 1990. Available online: http://www.card.iastate.edu/ publications/synopsis.aspx?id=833 (accessed on 14 September 2011).

13. Jonsson, H.; Vinneras, B. Adapting the Nutrient Content of Urine and Feces in Different Countries Using FAO and Swedish Data; In "Ecosan-Closing the Loop"-Proceedings of the 2nd International Symposium on Ecological Sanitation, Lübeck, Germany, 07-11 April 2003; Werner, C., Avendano, V., Demsat, S., Eicher, I., Hernandez, L., Jung, C., Kraus, S., Lacayo, I., Neupane, K., Rabiega, A., Wafler M., Eds.; GIZ: Bonn, Germany, 2004; pp. 623-626. 
14. Fry, J.; Merrill, R. Methane Digesters for Fuel Gas and Fertilizer, 8th ed.; Merrill, Y., Ed.; The New Alchemy Institute: Woods Hole, MA, USA, 1973.

15. Schouw, N.L.; Danteravanich, S.; Mosbaek, H.; Tjell, J.C. Composition of human excreta-A case study from southern Thailand. Sci. Total Environ. 2002, 286, 155-166.

16. Persson, S.P.E.; Barlett, H.D.; Branding, A.E.; Regan, R.W. Agricultural Anaerobic Digesters: Design and Operation; The Pennsylvania State University College of Agriculture; University Park, PA, USA, 1979. Available online: www.wcasfmra.org/biogas_docs/2010\%20NRAESAg\%20Digester\%20designs-1979.pdf (accessed on 14 September 2011).

17. Kaltwasser, B.J. Biogas-Regenerative Energieerzeugung durch Anaerobe Fermentation Organischer Abfälle in Biogasanlagen; Bauverlag: Berlin, Germany, 1980.

18. Balkwaste. Waste Treatment Technologies: Anaerobic Digestion, Waste Technology Database, 2009. Available online: http://www.wastedb.eu (accessed on 9 September 2011).

19. WaterAid. Construction of Ecological Sanitation Latrine; WaterAid: Kathmandu, Nepal, 2011. Available online: www.wateraid.org/documents/plugin_documents/technical_handbook construction_of_ecological_sanitation_latrine_5_september_2011.pdf (accessed on 5 December 2012).

20. Uddin, S.M.N.; Muhandiki, V.S.; Fukuda, J.; Nakamura, M.; Sakai, A. Assessment of social acceptance and scope of scaling up urine diversion dehydration toilets in Kenya. Journal of Water, Sanitation and Hygiene for Development, 2012, 3, 182-189.

21. FAO. Biogas Technology: A Training Manual for Extension. A System Approach to Biogas Technology; Sustainable Development Department, Food and Agriculture Organization/Consolidate Management Services: Kathmandu, Nepal, 1996. Available online: www.fao.org/sd/EGdirect/EGre0022.htm (accessed on 8 September 2011).

22. United Nations. Updated Guidebook on Biogas Development; Energy Resources Development Series, No. 27; United Nations: New York, NY, USA, 1984.

23. Liptak, B.G. Municipal Waste Disposal in the 1990's; Chilton Book Company: Randor, PA, USA, 1991.

24. Ludington, D. Calculation the Heating Value of Biogas; DLtech Inc.: Ithica, NY, USA, 2009. Available online: www.dairyfarmenergy.com/DLtech_Publications/Heating_Value_of_Biogas. pdf (accessed on 11 September 2011).

25. Liu, C.F.; Yuan, X.Z.; Zeng, G.M.; Li, W.W.; Li, J. Prediction of methane yield at optimum pH for anaerobic digestion of organic fraction of municipal solid waste. Bioresour. Technol. 2008, 99, 882-888.

26. World Health Organization. Water Sanitary and Health, 2012. Available online: http://www.who.int/water_sanitation_health/mdg1/en/index.html (accessed on 5 December 2012).

(C) 2012 by the authors; licensee MDPI, Basel, Switzerland. This article is an open access article distributed under the terms and conditions of the Creative Commons Attribution license (http://creativecommons.org/licenses/by/3.0/). 